Research article

\title{
Systematic wood anatomy of the tribes Euphorbieae and Hippomanieae (Euphorbiodeae, Euphorbiaceae) from India
}

\author{
Prem Prakash Jangid ${ }^{1 *}$, Soumana Datta ${ }^{2}$, Sandeep Yadav ${ }^{3}$ and Sangeeta Gupta ${ }^{1}$ \\ ${ }^{1}$ Wood Anatomy Discipline, Botany Division, Forest Research Institute, Dehradun, India \\ ${ }^{2}$ Department of Botany, University of Rajasthan, Jaipur, Rajasthan, India \\ ${ }^{3}$ Advance Research Centre for Bamboo and Rattan, Aizawl, Mizoram, India
}

*Corresponding Author: ppjangid2010@gmail.com

[Accepted: 10 February 2017]

\begin{abstract}
The present paper deals with detailed wood microstructure of 9 species belonging to six genera covering tribe Hippomaneae and Euphorbieae of the subfamily Euphorbiodeae (Euphorbiaceae). The study mainly focused on the systematic implication of wood anatomy to the subfamily, also ecological and evolutionary aspects were evaluated. Wood microstructure of the tribe Hippomaneae was found to be homogeneous considerably while Euphorbieae was heterogeneous to certain extent reflecting upon unnatural classification of the tribe. All the genera showed high vulnerability and mesomorphy reflecting adaptation to mesic environment. An identification key has been developed based on constant wood anatomical properties.
\end{abstract}

Keywords: Euphorbieae - Euphorbiaceae - Hippomaneae - Systematic - Wood anatomy.

[Cite as: Jangid PP, Datta S, Yadav S \& Gupta S (2017) Systematic wood anatomy of the tribes Euphorbieae and Hippomanieae (Euphorbiodeae, Euphorbiaceae) from India. Tropical Plant Research 4(1): 37-48]

\section{INTRODUCTION}

The subfamily Euphorbiodeae is one of the uniovulate subfamily of the spurge family Euphorbiaceae s.l., containing most of the species with white latex and is characterized by non-articulated laticifers and the flowers without a disc or petals (Webster 1994, Radcliffe-Smith 2001). Webster (1994) classified the subfamily into five tribes consisting of two large tribes, in addition to several more isolated genera that have been assigned to smaller tribes. One of these two large tribes is the Euphorbieae, distributed in tropical, subtropical and temperate regions around the world and characterized by its synapomorphic pseudanthial inflorescence (termed a cyathium) composed of gland-bearing involucres of several united bracts and their associated flowers and bracteoles. The tribe includes mainly the large genus Euphorbia L., as well as four other smaller genera in three subtribes (Esser 2012). Webster (1994) included 11 genera in three subtribes (Anthosteminae (Baill.) G. L. Webster, Neoguillauminiinae Croizat, and Euphorbiinae) in the tribe Euphorbieae. In India only one subtribe (Euphorbiinae) occur with 3 genera ( pedilanthus, Euphorbia and synadenium) and 84 species (Balakrishnan \& Chakrabarty 2007). The second large tribe of Euphorbioideae is the Hippomaneae A.Juss. ex Bartl., pantropical (with only few extratropical species) distributed in tropical America, Africa, asia and Australia. The Hippomaneae do not include any single, large genera, but rather a larger number of smaller genera, several of them monotypic. Floral bud of the tribe is unique and quite unlike any other euphorboid type (Esser 1997). Esser (1994), Esser et al. (1998) and Esser (2001) proposed the generic circumscription of the tribe. Balakrishnan \& Chakrabarty (2007) even considered the tribe of such importance that they proposed a separate subfamily (Hippomanioideae Chakrab. \& N.P.Balakr.) for the tribe. According to Esser (2012) the tribe comprise 33 genera and $c a .300$ species of mostly woody plants (with few herbs and succulents. In Webster (1994) circumscription the tribe hippomaneae comprises 19 genera in three subtribes (Carumbiinae Müll.Arg., Mabeinae Pax \& K.Hoffm., and Hippomaninae) and 24 genera in two subtribes (Carumbiinae and Hippomaninae) in circumscription of Radcliffe-smith (2001). This tribe is represented by only subtribe (Hippomaninae) with 6 genera viz. microstachys, Balakata, Shirakoipsis, Triadica, Excoecaria and Falconeria. 
Gross wood microstructure of the subfamily Euphorbiodeae has been studied by Raturi et al. (2001); Mennega (2005) studied wood structure of sub-tribe Flueggeinae and Securineginae; Bamber (1974) reported thin to thick walled libriform fibres (Type I). Metcalfe \& Chalk (1950) general microstructure of some genera. Pearson \& Brown (1932) studied wood microstructure of Excoecaria agallocha. Gamble (1922) studied gross wood structure. The tribe Hippomaneae and Euphorbieae are the most controversial from systematic point of view in the subfamily Euphorbiodeae. Thus the present study was performed to understand the systematic implication of wood microstructure in Hippomaneae and Euphorbieae tribes.

\section{MATERIAL AND METHODS}

The present study is based on examination of 24 wood specimens of 9 species belonging to 6 genera of tribe's Hippomaneae and Euphorbieae of the subfamily Euphorbiodeae (Euphorbiaceae), available in Xylarium of Forest Research Institute, Dehradun (Table 1). For microscopic examination 15-20 $\mu \mathrm{m}$ thick cross, radial and tangential sections were cut on Reichert microtome. The sections were stained with Heidenhain's haematoxylin and safranin and permanent slides were prepared by following standard laboratory procedures. All samples were macerated by following Schultz's method (30\% nitric acid and a pinch of potassium chlorate). IAWA terminology (IAWA 1989) has been followed for writing the anatomical descriptions. The two ecological indices, vulnerability and mesomorphy, given by Carlquist (1988) of the genera under study was evaluated as per following formulae:

$$
\text { Vulnerability }=\text { Mean vessel diameter } / \text { Mean vessel frequency }
$$

Mesomorphy $=$ Vulnerability $\mathrm{X}$ Mean vessel element length

Table 1. Details of wood samples studied of the subfamily Euphorbiodeae.

1. Balakata baccata (Roxb.) Esser (Sapium baccatum Roxb.); DDw 1962, Chittagong, B.D.; DDw 6538, Rangoon, Myanmar; DDw 8207, Buxa Div, W.B.; DDw 8238, Kameng, Arp.

2. Euphorbia neriifolia L.; DDw 7174, Dornal Forest.

3. Euphorbia royleana Boiss.; DDw 3075, Sabathu, Pune.

4. Euphorbia tirucalli L.; DDw 3509, Khirda, Orissa

5. Euphorbia tortilis Rottler ex Ainslie; DDw 5694, Coimbture, T.N.

6. Excoecaria agallocha L.; 2477, Andamans; DDw 6703, Bombay; DDw 7298, Sunderbans, W.B; DDw 7301, Sunderbans, W.B; DDw 7304, Sunderbans, W.B; DDw 7361, Khutna, W.B; DDw 7470, Sunderbans, W.B.

7. Falconeria insignis Royle (Sapium insigne (Royle) Benth. \& Hook.f.; DDw 615, Kullu, H.P.; DDw 5862, Dehradun, U.A.; DDw 5863, Dehradun, U.A.; DDw 6471, Rangoon, Myanmar.

8. Shirakoipsis indica (Willd.) Esser (Sapium indicum Willd.); DDw 6507, Sunderbans, W.B.

9. Triadica sebifera (L.) Small (Sapium sebiferum (L.) Roxb.); DDw 3114, Dehradun, U.A.; DDw 7423, Dehradun, U.A.; DDw 7424, Dehradun, U.A.; DDw 7487, Dehradun, U.A.

\section{RESULTS}

\section{Wood Microstructure Descriptions \\ Balakata Esser}

Containing two species from NE India to Vietnam and throughout SE Asia, up to parts of New Guinea, of these only one found in India (Balakrishnan \& Chakrabarty 2007) studied here.

Species studied: Balakata baccata (Roxb.) Esser (= Sapium baccatum Roxb.)

Physical features: Wood white to yellowish white, turning to greyish yellow on ageing, soft and light to very

light, straight grained and medium coarse textured, specific gravity ranging between $0.32-0.48$ air dry

Microscopic features: Vessels frequency 7 (4-14) per $\mathrm{mm}^{2}$, mostly solitary vessels with some radial multiples of $2-3$, rarely clusters present. Vessel outline rounded to oval, average tangential diameter 144 (83-206) $\mu \mathrm{m}$, mean vessel element length 610 (481-749) $\mu \mathrm{m}$ (Tables $2 \& 3$ ). Intervessel pits alternate, rounded, distinctly bordered with $7.8(5.5-13.7) \mu \mathrm{m}$ diameters. Perforation plate simple. Tyloses common. Vessel ray pits simple, much reduced bordered, rounded to elliptical with 10.7 (8.2-13.7) $\mu$ m diameters. Fibres non-septate, thin walled with distinctly bordered pits on radial walls only (Fig. 1G). Average fibre length 1089 (856- 


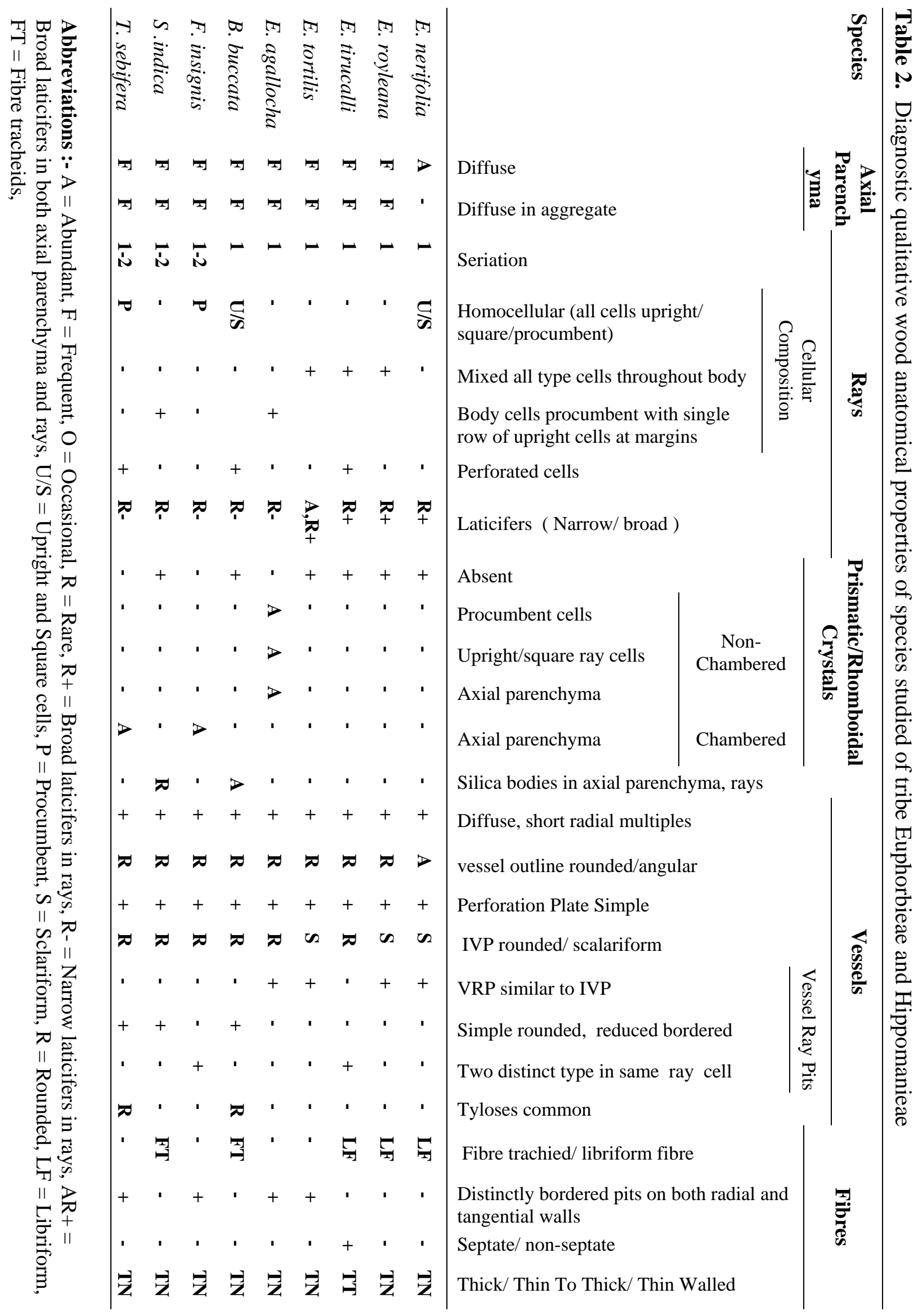




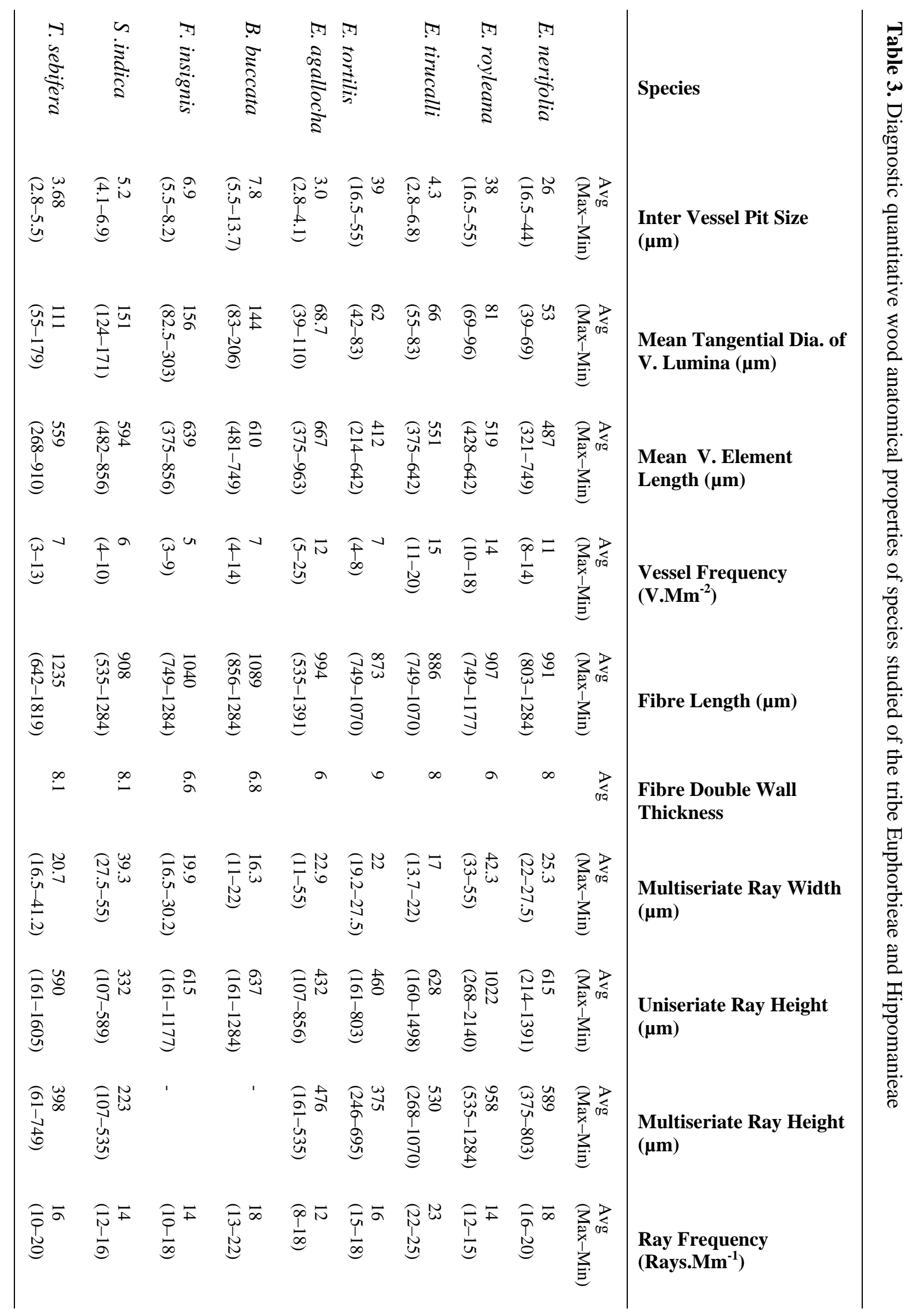



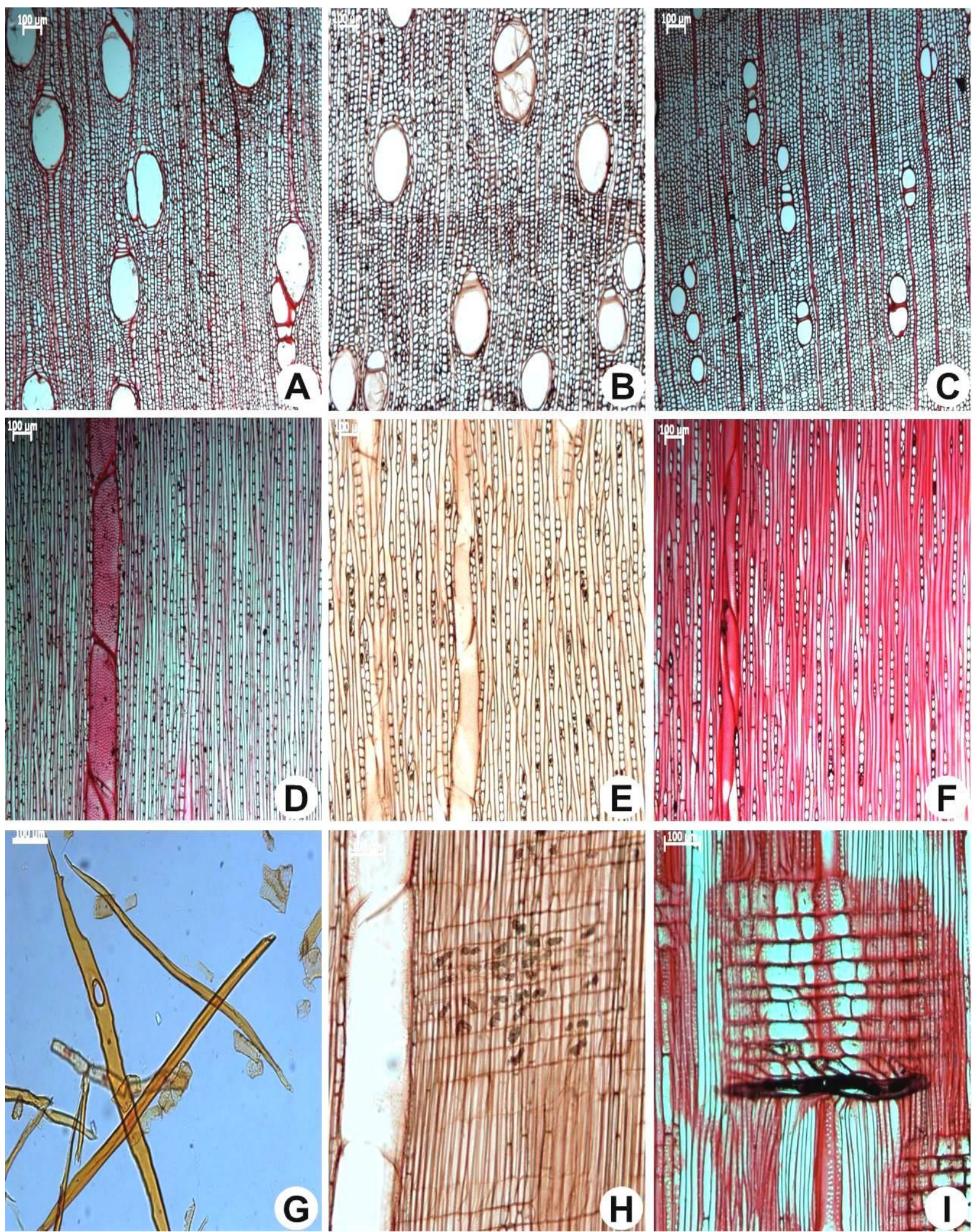

Figure 1. A-C, T.S. showing diffuse to diffuse-in-aggregates axial parenchyma in Balakata buccata (A), Shirakiopsis indica (B) and Excoecaria agallocha (C); D-F, T.L.S. showing exclusively uniseriate rays and intervessel pits in B. baccata (D), S. indica (E) and E. agallocha $(\mathbf{F}) ; \mathbf{G}$, Maceration showing thin walled fibres and intrusive cavity in B. buccata. H, R.L.S. showing homocellular rays containing silica bodies in $S$. indica; $\mathbf{I}$, laticifers in rays in E. agallocha.

1284) $\mu \mathrm{m}$, average fibre diameter $26.3(19.2-33.0) \mu \mathrm{m}$, double wall thickness $6.8 \mu \mathrm{m}$. Parenchyma frequent, diffuse to diffuse in aggregates and scanty paratracheal (Fig. 1A). Silica bodies present. Rays 17.7 (13-22) per mm, exclusively uniseriate (Fig. 1E). Average uniseriate ray height $637(161-1284) \mu \mathrm{m}$ with 245 cells. Average ray width 16.3 (11-22) $\mu \mathrm{m}$ (Table $2 \& 3$ ). Rays homocellular, composed of mostly upright/square cells only. Frequently silica bodies present. 


\section{Euphorbia L.}

Cosmopolitan, mainly in tropical, subtropical and warm temperate regions around the world, ca. 2000 species. 82 species belonging to 6 subgenera found in India (Balakrishnan \& Chakrabarty 2007). In present study four species described of subgenus Euphorbia, out of 17 species in India.

Species studied: Euphorbia neriifolia L., Euphorbia royleana Boiss., Euphorbia tortilis Rottler ex Ainslie, Euphorbia tirucalli L.

Physical features: The wood is yellowish brown, soft and fine textured, specific gravity ranging between $0.21-$ 0.52 air dry.

Microscopic features: Vessel frequency 12 (4-20) per $\mathrm{mm}^{2}$, radial multiples of 2-3 cells common with many solitary vessels and rarely clusters. Vessel outline rounded, average tangential diameter $65.5(39-96) \mu \mathrm{m}$, mean vessel element length 492 (214-749). Perforation plate simple. Inter vessel pits scalariform and similar vessel ray pits present in E. nerifolia, E. tortilis and E. royleana (Fig. 2I). E. tirucalli containing alternate, rounded to elliptical distinct bordered intervessel pits with $4.3(2.8-6.8) \mu \mathrm{m}$ diameters and simple, reduced bordered, rounded vessel ray pits. Fibres non-septate, thin walled, libriform fibres present in E. nerifolia, E. tirucalli and E. royleana (Fig. 2H). E. tortilis contains fibres with distinctly bordered pits on both radial and tangential walls. 914 (749.0-1284) $\mu \mathrm{m}$ long, diameter 32 (25-38) $\mu \mathrm{m}$. Double wall thickness $7.7 \mu \mathrm{m}$. Parenchyma frequent, diffuse to diffuse in aggregate and scanty paratracheal (Fig. 2A-C). Rays 18 (12-25) $/ \mathrm{mm}$, exclusively uniseriate (Fig. 2D-F). Some rays contain radial laticifers in all species. Laticifers large in size and surrounded by cluster of secretory cells (Fig. 2E). Average uniseriate ray height $681(160-2140) \mu \mathrm{m}$ with 2-25 cells. Average multiseriate ray width 27 (13.7-55.0) $\mu \mathrm{m}$, ray height 613 (268-1284) $\mu \mathrm{m}$ with 616 cells (Tables $2 \& 3$ ). Rays heterocellular composed of procumbent and square/upright cells mixed throughout body (Fig. 2G) except E. neriifolia containing homocellular rays made up of upright/square cells only. Perforated ray cells present in E. tirucalli. Both Radial and axial laticifers found in E. tortilis only.

\section{Excoecaria L.}

A Paleotropical genus of about 40 species, most in tropical Asia but a few taxa in Africa, Madagascar, and Tropical Australia. 6 species (including cultivated one) represented in India (Balakrishnan \& Chakrabarty 2007), of which one species studied here.

Species studied: Excoecaria agallocha L.

Physical features: Wood white or greyish yellow to pale yellow, soft, light, straight grained and medium coarse textured, specific gravity ranging between $0.35-0.52$ air dry.

Microscopic features: Vessels frequency 12 (5-25) per $\mathrm{mm}^{2}$, radial multiples of 2-3 common with some solitary vessels, few long multiples and clusters present. Vessel outline rounded to oval, average tangential diameter 68.7 (39-110) $\mu \mathrm{m}$. Mean vessel element length 667 (375-963) $\mu \mathrm{m}$ (Tables $2 \&$ 3). Intervessel pits alternate, polygonal, distinctly bordered with 2.9 (2.8-4.1) $\mu \mathrm{m}$ diameters. Perforation plate simple. Tyloses common. Vessel-ray pits similar to intervessel pits. Fibres non-septate, thin walled with distinctly bordered pits on both radial and tangential walls. Average fibre length $994.4(535-1391) \mu \mathrm{m}$, average fibre diameter 28.2 (19.2-41.2) $\mu \mathrm{m}$, double wall thickness $6 \mu \mathrm{m}$. Parenchyma frequent, diffuse to diffuse in aggregates sometime forming interrupted fine lines and scanty paratracheal (Fig. 1C). Frequently non-chambered prismatic/rhomboidal crystal present. Rays 12.2 (8-18) per mm, exclusively uniseriate (Fig. 1E). Average uniseriate ray height 432 (107-856) $\mu \mathrm{m}$ with 2-28 cells and width 22.9 (11-55) $\mu \mathrm{m}$. Rays heterocellular, composed of procumbent body cells with single row of upright and square cells at marginal ends (Fig. 2I). Frequently non-chambered prismatic/rhomboidal crystal present. Some rays containing radial laticifers. Laticifers small in size, not surrounded by secretory cells (Fig. 2I).

\section{Falconeria Royle}

Monotypic genus distributed in India and Sri Lanka to Vietnam and China (Balakrishnan \& Chakrabarty 2007).

Species studied: Falconeria insignis Royle (= Sapium insigne (Royle) Benth. \& Hook.f.)

Physical features: Wood white to yellowish white, turning to greyish yellow on ageing, soft and light to very light, straight grained and medium coarse textured, specific gravity ranging between 0.39-0.50 air dry.

Microscopic features: Vessels frequency 5 (3-9) per $\mathrm{mm}^{2}$, mostly solitary vessels with some radial multiples of 2-3, rarely clusters present. Vessel outline rounded to oval, average tangential diameter $156(82.5-303) \mu \mathrm{m}$, mean vessel element length 639 (375-856) $\mu \mathrm{m}$. Intervessel pits alternate, rounded, distinctly bordered with 

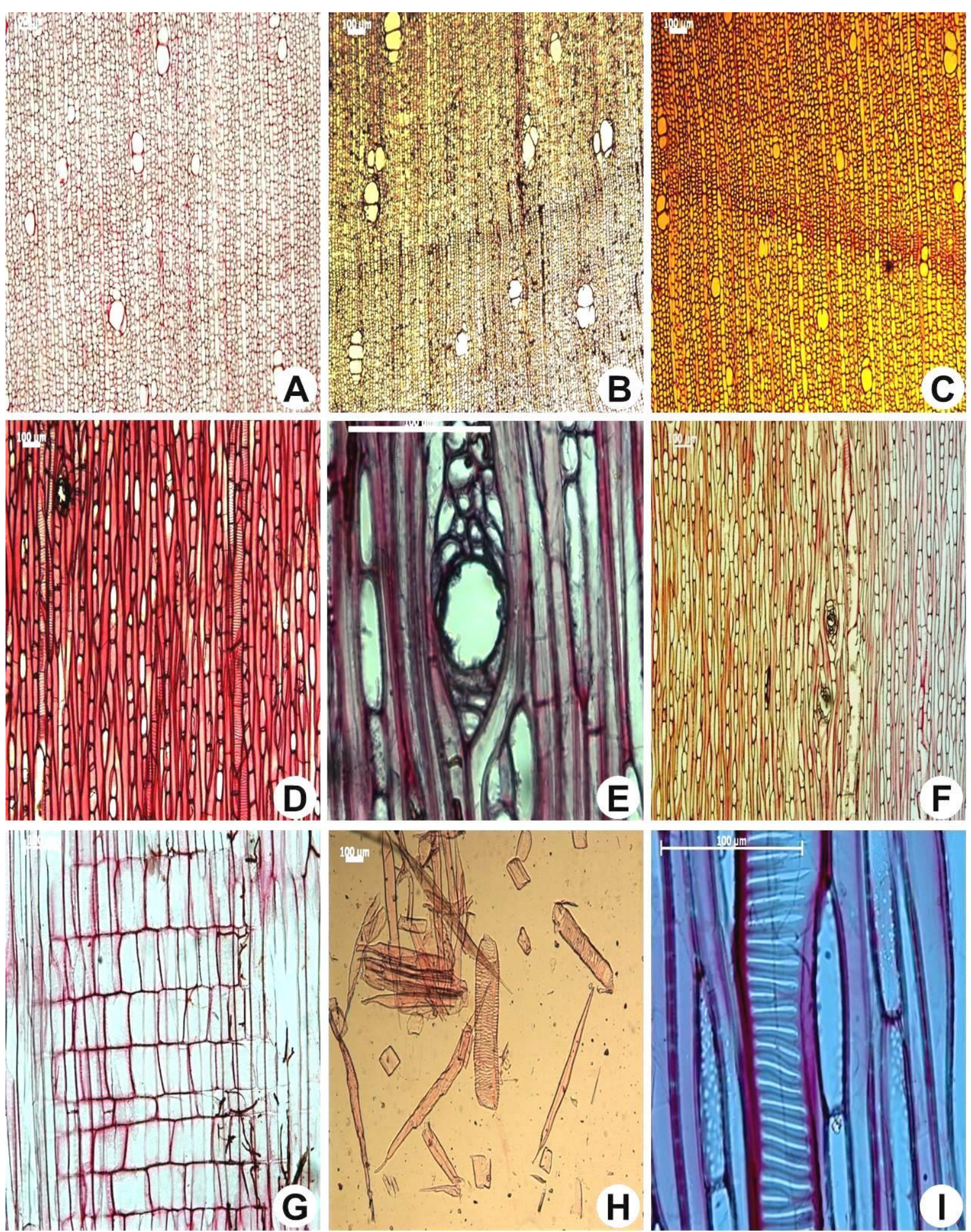

Figure 2. A-C, T.S. showing diffuse to diffuse-in-aggregates axial parenchyma in Euphorbia royleana (A), E. tirucalli (B) and E. nerifolia $(\mathbf{C})$; D-F, T.L.S. showing exclusively uniseriate rays and radial laticifers in E. royleana (D), E. tirucalli (E) and E. nerifolia $(\mathbf{F})$; G, R.L.S. showing heterocellular rays made up of procumbent and upright/square cells mixed throughout body in E. royleana; $\mathbf{H}$, Maceration showing fibres and vessel elements in E. tirucalli; $\mathbf{I}$, scalariform intervessel pits in E. nerifolia.

6.9 (5.5-8.2) $\mu \mathrm{m}$ diameters. Perforation plates simple. Tyloses common. Vessel ray pits two distinct types (rounded to elliptical and horizontal), much reduced bordered in same ray cells. Fibres non-septate, thin walled with distinctly bordered pits on radial walls only. Average fibre length 1040 (749-1284) $\mu \mathrm{m}$, average fibre diameter $31(22.0-41.2) \mu \mathrm{m}$, double wall thickness $6.6 \mu \mathrm{m}$. Parenchyma frequent, diffuse to diffuse in aggregates and scanty paratracheal. Abundant chambered crystal present in series up-to 10. Rays 14 (10-18) www.tropicalplantresearch.com 
per mm, exclusively uniseriate. Average uniseriate ray height 614.5 (161-1177) $\mu \mathrm{m}$ with 4-23 cells and width 19.9 (16.5-30.2) $\mu \mathrm{m}$ (Tables 2 \& 3). Rays homocellular, composed of procumbent cells only. Rarely chambered/ non-chambered, prismatic/rhomboidal crystal present.

\section{Shirakiopsis Esser}

Containing 6 species distributed in tropical Africa and Asia, from India to Combodica and throughout Malaysia. Only type species represented in India (Balakrishnan \& Chakrabarty 2007) studied here.

Species studied: Shirakoipsis indica (Willd.) Esser (Sapium indicum Willd.)

Physical features: Wood white to yellowish white, turning to greyish yellow on ageing, soft and light to very light, straight grained and medium coarse textured, specific gravity ranging between $0.40-0.55$ air dry.

Microscopic features: Vessels frequency 6 (4-10) per $\mathrm{mm}^{2}$, radial multiples of 2-3 common with many solitary vessels, rarely clusters present. Vessel outline rounded to oval, average tangential diameter 151 (124-171) $\mu \mathrm{m}$. Mean vessel element length 594 (482-856) $\mu \mathrm{m}$. Intervessel pits alternate, rounded, distinctly bordered with $5.2(4.1-6.9) \mu \mathrm{m}$ diameters (Tables $2 \& 3$ ). Perforation plate simple. Tyloses absent. Vessel ray pits simple, reduced bordered, rounded to elliptical $6.9(5.5-8.2) \mu \mathrm{m}$. Fibres non-septate, thin walled with distinctly bordered pits on radial walls. Average fibre length $908(535-1284) \mu \mathrm{m}$, average fibre diameter $33.8(24.7-46.7) \mu \mathrm{m}$, double wall thickness $8.1 \mu \mathrm{m}$. Parenchyma frequent, diffuse to diffuse in aggregates and scanty paratracheal (Fig. 1B). Silica bodies present. Rays 14 (12-16) per mm, mostly uniseriate with few locally biseriate (Fig. 1E). Average uniseriate ray height 332 (107-589) $\mu \mathrm{m}$ with $3-12$ cells. Average biseriate ray width 39.3 (27.5-55.0) $\mu \mathrm{m}$ and height 223 (107-535) $\mu \mathrm{m}$ with $3-15$ cells. Rays heterocellular, composed of procumbent body cells with single row of upright and square cells at marginal ends. Abundant silica bodies present (Fig. 1H). Crystal absent.

\section{Triadica Lour.}

About 4 species distributed in Asia, NE. India to China, Indo-China and West Malaysia. Two species represented in India (Balakrishnan \& Chakrabarty 2007), of which type species is studied here.

Species studied: Triadica sebifera (L.) Small (= Sapium sebiferum (L.) Roxb.)

Physical features: Wood white to yellowish white, turning to greyish-yellow on ageing, soft and light to very light, straight grained and medium coarse textured, specific gravity ranging between $0.50-0.59$ air dry.

Microscopic features: Vessels frequency 7 (3-13) per $\mathrm{mm}^{2}$, radial multiples of 2-3 common with some solitary vessels, rarely clusters present. Vessel outline rounded to oval, average tangential diameter $111(55-179)$ $\mu \mathrm{m}$, mean vessel element length 558.8 (268-910) $\mu \mathrm{m}$ (Tables $2 \& 3$ ). Intervessel pits alternate, rounded, distinctly bordered with 3.7 (2.8-5.5) $\mu \mathrm{m}$ diameters. Perforation plate simple. Tyloses absent. Vessel ray pits distinctly bordered similar to intervessel pits with $4.6(2.8-6.9) \mu \mathrm{m}$. Fibres non-septate, thin walled with distinctly bordered pits on both radial and tangential walls. Average fibre length 1235 (642-1819) $\mu \mathrm{m}$, average fibre diameter $22(28.5-49.2) \mu \mathrm{m}$, double wall thickness $8.1 \mu \mathrm{m}$. Parenchyma frequent, diffuse to diffuse in aggregates and scanty paratracheal. Abundant chambered crystal present in series up-to 10. Rays $16(10-20)$ per mm, mostly uniseriate with few locally biseriate. Average uniseriate ray height 590.7 (1611605) $\mu \mathrm{m}$ with 4-48 cells. Average biseriate ray width 20.7 (16.5-41.2) $\mu \mathrm{m}$ and height 398.5 (61-749) $\mu \mathrm{m}$ with 3-25 cells. Rays homocellular, composed of procumbent cells only. Crystal absent. Perforated ray cells present.

\section{Identification key to Indian species of the subfamily Euphorbiodeae}

1. Radial laticifers broad and surrounded by subsidiary cells, frequently crystals present in rays and axial

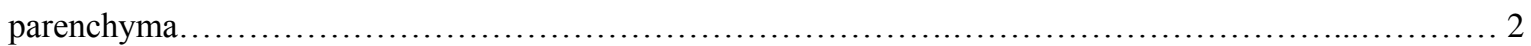

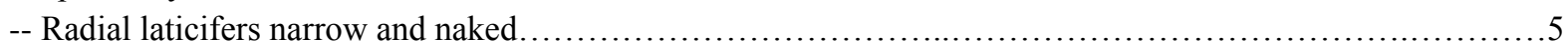

2. Fibre non-septate, intervessel pits scalariform, vessel ray pits similar to intervessel pits...................... 3

-- Fibre septate, intervessel pits rounded to elliptical, vessel ray pits two distinct type in same ray

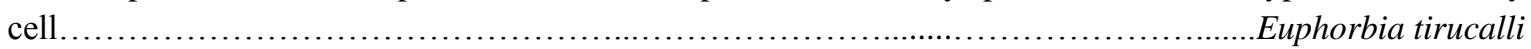

3. Distinctly bordered pits present on both radial and tangential walls of fibres, both radial and axial laticifers present. Euphorbia tortilis

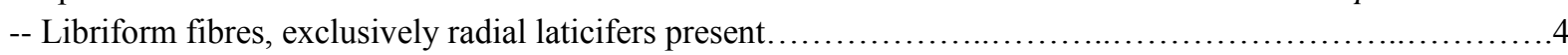

4. Rays made up of upright/square cells only.

Euphorbia neriifolia

-- Rays made up of mixed upright/square and procumbent cells throughout of body..... Euphorbia royleana 
5. Vessel ray pits similar to intervessel pits. .66

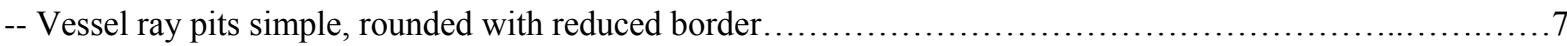

6. Homocellular rays made up of procumbent cells only......................................Triadica sebifera

-- Heterocellular rays made up of procumbent body cells and single row of upright/square cells at marginal

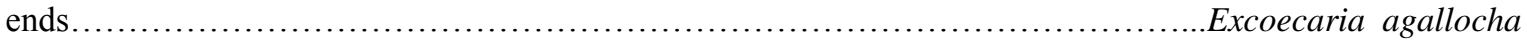

7. Fibre trachied present, crystals absent, silica bodies present in axial parenchyma and ray cells................8

-- Distinctly bordered pits present on both radial and tangential walls of fibres, chambered crystal present in axial parenchyma, silica bodies absent...............................................Falconeria insignis

8. Homocellular rays made up of upright/square cells only, tyloses present....................Balakata buccata

-- Heterocellular rays composed of procumbent body cells and single row of upright/square cells at marginal

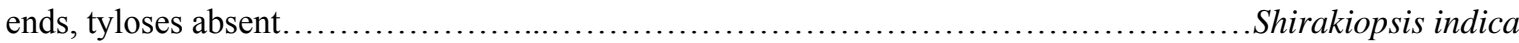

\section{DISCUSSION AND CONCLUSION}

Webster (1994) and Radcliffe-Smith (2001) classified the subfamily into five tribes. Euphorbioideae consist of two large tribes, in addition to several more isolated genera that have been assigned to smaller tribes. Webster (1994) included 11 genera in three subtribes (Anthosteminae (Baill.) Webster, Neoguillauminiinae Croizat, and Euphorbiinae) in the tribe Euphorbieae. In India only one subtribe (Euphorbiinae) occurs with 3 genera (Pedilanthus, Euphorbia and Synadenium) and 84 species (Balakrishnan \& Chakrabarty 2007). According to Esser (2012) the tribe comprise 33 genera and ca. 300 species of mostly woody plants (with few herbs and succulents. In Webster (1994) circumscription the tribe Hippomaneae comprises 19 genera in three subtribes (Carumbiinae Müll.Arg., Mabeinae Pax \& K.Hoffm., and Hippomaninae) while 24 genera in two subtribes (Carumbiinae and Hippomaninae) in circumscription of Radcliffe-Smith (2001). This tribe is represented by only subtribe (Hippomaninae) with 6 genera viz. Microstachys, Balakata, Shirakoipsis, Triadica, Excoecaria and Falconeria.

\section{Tribe Hippomaneae}

We studied five genera viz. Excoecaria, Triadica, Shirakoipsis, Balakata and Falconeria, out of six genera of the tribe Hippomaneae represented in India. Webster (1994) included the genera Triadica, Shirakoipsis, Balakata and Falconeria in the genus Sapium Jacq. Sapium has been considered a genus of about 100 species in circumscription of Pax \& Hoffmann 1912 and Webster 1994. Further morphological phylogeny of Hippomaneae by Kruijt (1996) and Esser (2001) supporting the, rearrangement of the previously unnatural Sapium into several distinct genera and proposed a new overall generic classification of the Hippomaneae based on a worldwide morphological survey of members of all genera and sections of the tribe. A number of species recently been excluded from Sapium by Kruijt (1996) and Esser (1999, 2002), so that the actual number of currently accepted species is around 20 only (Esser 2012).

We studied one species from each of five genera of tribe Hippomaneae. Excoecaria showed some difference in vessel diameter, vessel ray pitting and crystal deposition from other four genera studied. The wood microstructure of four genera viz. Balakata, Shirakoipsis, Falconeria and Triadica found uniform to certain extent. Quantitative wood anatomical properties were nearly constant in all species studied of these four genera. A little variation was noted in only qualitative features like fibre wall pitting ray cellular composition and crystal/silica deposition in parenchyma and rays. Balakata buccata have exclusively uniseriate rays while other three species $F$. insignis, $T$. sebifera and $S$. indica have predominantly uniseriate rays with few locally bi-seriate rays. B. buccata and $S$. indica contains silica bodies and lack of crystals, whereas $F$. insignis and $T$. sebifera contain chambered crystals in axial parenchyma and lack of silica bodies.

The generic distinctiveness between Sapium (Mennega 2005) and these four genera were noted in presence of crystals in ray cells and absence of silica bodies in Sapium unlike the Balakata, Triadica, Falconeria and Shirakoipsis. Present study supports the segregation of the genera viz. Balakata, Shirakoipsis, Triadica and Falconeria from the genus Sapium by Esser (1999, 2002) and Kruijt (1996).

\section{Tribe Euphorbieae}

According to circumscription of Webster (1994), the subtribe contains seven genera: Chamaesyce Gray, Cubanthus (Boiss.) Millsp., Endadenium Leach, Euphorbia, Monadenium Pax, Pedilanthus Necker ex Poit., and Synadenium Boiss. Most authors treat these as infrageneric taxa of Euphorbia. We studied only genus 
Euphorbia out of three genera (Pedilanthus, Euphorbia and Synadenium) of subtribe Euphorbiinae represented in India.

The integrity of the genus Euphorbia has long been questioned, and many $20^{\text {th }}$ century workers (Carter 1988, 1992, Gilbert 1987, Balakrishnan \& Chakrabarty 2007) favouring subdivision of this vast genus into two or more genus. There are 9 to 11 generally recognized subgenera. Seven sub-genera occurs in India (Balakrishnan \& Chakrabarty 2007), of these our species falls in Euphorbia subg. Euphorbia.

There was great deal of variation in qualitative wood anatomy of species studied of genus Euphorbia viz. E. nerifolia, E. royleana, E. tirucalli and E. tortilis. E. tirucalli has distinct wood microstructure from other three species, differential wood character found are, thin to thick walled septate fibres, small alternate intervessel pits, vessel ray pits simple, rounded to elliptical unlike rest of species. Similarily, E. tortilis differ from E. tirucalli, E. nerifolia and E. royleana in features such as presence of distinctly bordered pits on both radial and tangential walls of fibres and presence of axial laticifers. On other hand E. royleana and E. nerifolia have similar wood microstructure to certain extent.

In Webster (1994) infra-generic classifications of the Euphorbia, he included the four species studied here in Euphorbia subg. Euphorbia. According to present study these species should not be maintained in same infrageneric group (Euphorbia subg. Euphorbia) due to considerable wood anatomical dissimilarities among species. Euphorbia subg. Euphorbia further can be classified in three different groups at section or subgenus level.

Group I: axial and radial laticifers present, scalariform intervessel pits and non-septate fibres with distinctly bordered pits on both radial and tangential walls. Species falls in this group is E. tortilis.

Group II: exclusively radial laticifers present, scalariform intervessel pits and non-septate libriform fibres. Species falls in this group are E. royleana and E. nerifolia.

Group III: exclusively radial laticifers present, rounded to elliptical intervessel pits and septate libriform fibres. Species falls in this group is E. tirucalli.

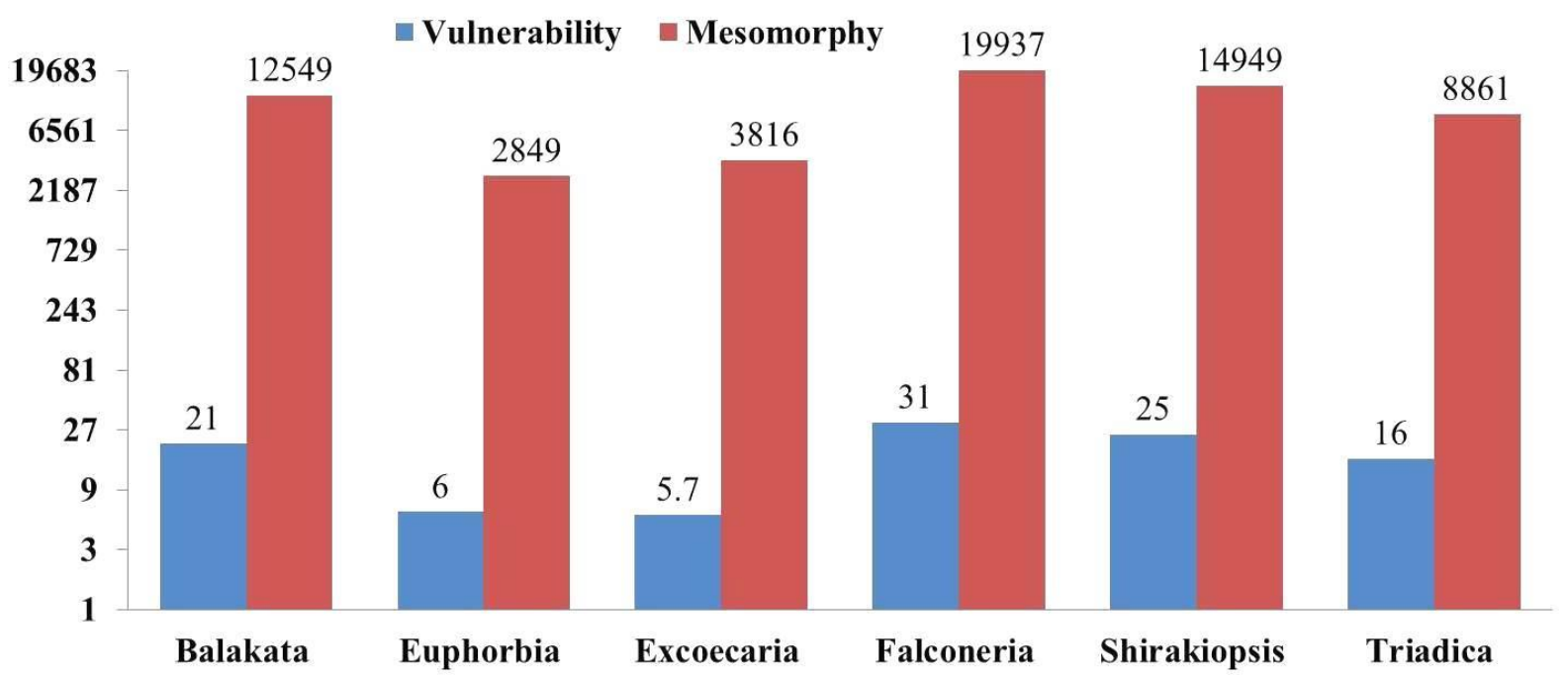

Figure 3. Graph showing vulnerability and mesomorphy values and their relationship within subfamily Euphorbiodeae.

\section{Ecological consideration}

Vulnerability and Mesomorphy are two indices proposed by Carlquist (1977) as ecological indicators for wood anatomy trends. According to Carlquist (2001), the values of vulnerability index lower than one $(<1)$ reflect adaptation to drier areas, while values greater than three $(>3)$ are found in plants living in areas with high water availability. For mesomorphy index, values less than 100 indicate plants which grow in dry environments (xeric) or in regions with a dry period for several months in the year, while higher mesomorphy index values (>200) are found in species which grow in mesic environments. Plants adapted to water stress environments have higher vessel grouping.

In the present study, all the genera showed relatively higher values of vulnerability and mesomorphy indices (Fig. 3). Euphorbia showed lowest values of vulnerability (6) and mesomorphy (2849) whereas Falconeria showed highest values of vulnerability (31) and mesomorphy (19937). Addition to this, presence of high vessel groupings (Carlquist 1966) and relatively narrower vessels with higher frequencies (Baas et al. 1983, Carlquist www.tropicalplantresearch.com 
\& Hoekman 1985) and thicker fibre walls (Alves \& Angyalossy 2002, Barajas-Morales 1985, Luchi et al. 2005) also represent adaptation to xeric environment. Higher values of mesomorphy and vulnerability indices within the subfamily showed its adaptation to mesic environment which is favoured by presence of very thin fibres, banded parenchyma and wide vessels with low frequencies which are more efficient in water conduction than narrow ones (Baas et al. 1983, Zimmermann 1983).

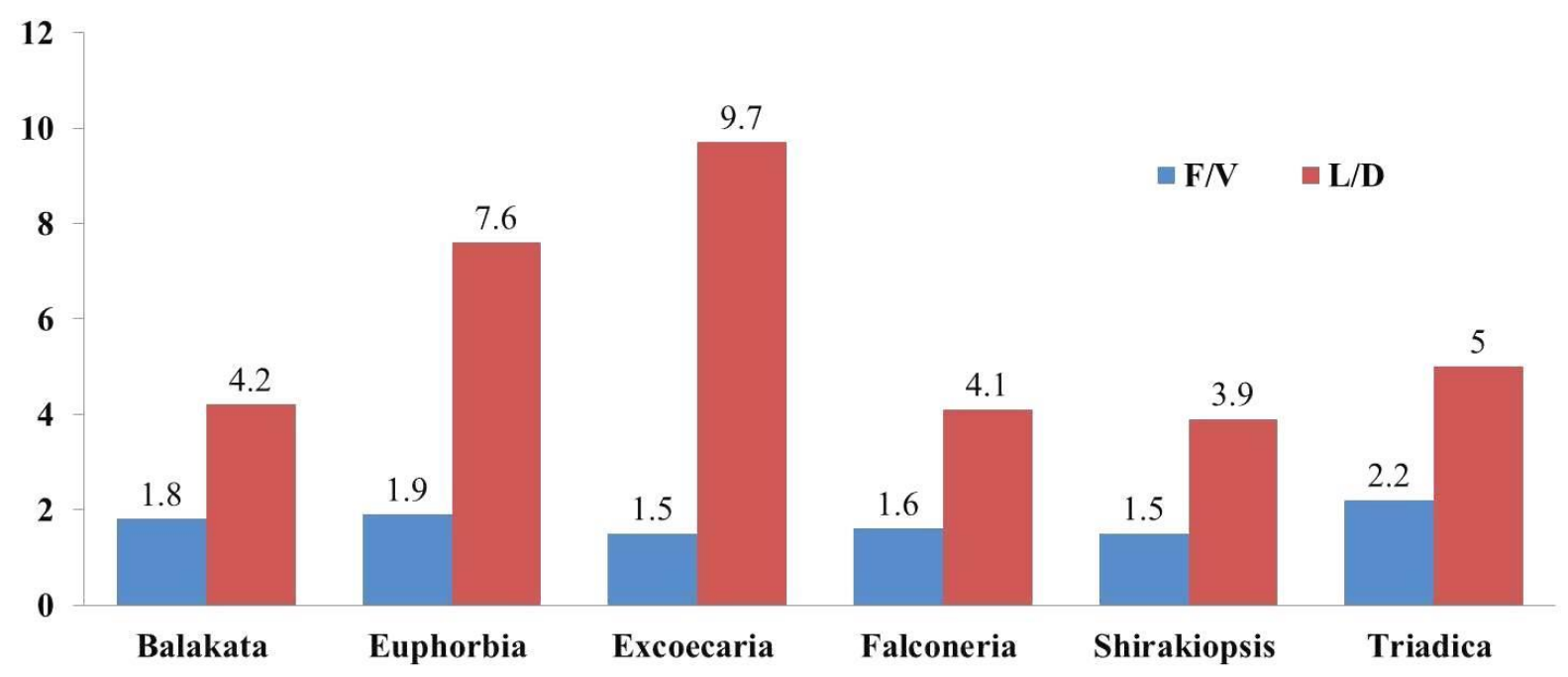

Figure 4. Graph showing F/V and L/D values and their relationship within subfamily Euphorbiodeae.

\section{Evolutionary consideration}

According to the major trends of specialization in secondary xylem of dicotyledons (Yatsenko-Khmelevskyi 1954) and Carlquist (2001), wood anatomical features interpreted as primitive characters are, diffuse to diffuse in aggregate parenchyma, long thick walled non-septate fibres, bordered pits on both radial and tangential walls and small diameter of vessels, long vessel element, scalariform perforation plates, vessel ray pits similar to intervessel pitting and absence of helical sculpture on fibre walls. According to Kribs (1935) relatively narrow rays, presence of heterocellular, both uniseriate and multiseriate rays together are primitive characters. According to Mennega (1987) the combination of characters considered most advanced includes vessel with simple perforation plates, medium sized vessel element, small intervessel and vessel-ray pitting, axial parenchyma absent/rare or scanty paratracheal and thin walled, septate libriform fibres.

In the species studied of the subfamily Euphorbiodeae, almost all the wood anatomical features are evident of advancement such as presence of simple perforation plates, exclusively uniseriate rays, alternate intervessel pits, relatively wider and shorter vessel elements and thin walled libriform fibres except Excoecaria and Euphorbia. Excoecaria contains some primitive features also such as minute intervessel pits and vessel ray pitting similar to intervessel pits and fibres with distinctly bordered pits on both radial and tangential walls, similarly Euphorbia contains scalariform intervessel pits and vessel ray pitting similar to intervessel pits.

Length, width ratio of vessels (L/D), fibre and vessel element length ratios (F/V) normally serve as indices of phylogenetic advancement (Bailey 1957). High L/D and concomitantly low F/V values are widely regarded as primitive (Rury 1985). In the present study lowest F/V (1.5) and highest L/D (9.7) values were found for Excoecaria. On other hand highest F/V (2.2) and lowest L/D (5) values were found for Triadica (Fig. 4).

\section{REFERENCES}

Alves ES \& Angyalossy AV (2002) Ecological trends in the wood anatomy of some Brazilian species. 2. Axial parenchyma, rays and fibres. IAWA Journal 23: 391-418.

Baas P, Werker E \& Fahn A (1983) Some ecological trends in vessel characters. IAWA Bulletin 4: 141-159.

Balakrishnan NP \& Chakrabarty T (2007) The family Euphorbiaceae in India, a synopsis of its profile, taxonomy and bibliography. Bishen Singh and Mahendra Pal Singh, Dehradun, India, $500 \mathrm{p}$.

Bamber RK (1974) Fibre types in the wood of Euphorbiaceae. Australian Journal of Botany 22: 629-63.

Barajas-Morales J (1985) Wood structural differences between trees of two tropical forests in Mexico. IAWA Bulletin 6: 355-364. 
Carlquist S (1966) Wood anatomy of Compositeae: a summary, with comments on factors controlling wood evolution. Aliso 6 (2): 25-44.

Carlquist S (1977) Ecological factors in wood evolution: A floristic approach. American Journal of Botany 64 (7): 887-896.

Carlquist S (1988) Comparative wood anatomy: systematic and evolutionary aspects of dicotyledons woods. Springer Verlag, Berlin, Germany.

Carlquist S (2001) Comparative wood anatomy: systematic and evolutionary aspects of dicotyledons woods, $2^{\text {nd }}$ Edition. Springer-Verlag, Berlin, Germany.

Carlquist S \& Hoekman DA (1985) Ecological wood anatomy of the woody southern Californian Flora. IAWA Bulletin 6: 319-347.

Carter S (1988) Euphorbiaceae, Tribe Euphorbieae. In: Polhill RM (ed) Flora of Tropical East Africa: Euphorbiaceae, Volume 2. pp. 409-564.

Carter S (1992) New species of Euphorbia subgenus Tirucalli (Euphorbiaceae) from Somalia and Oman. Nordic Journal of Botany 12(6): 675-679.

Esser HJ (1994) Systematische Studien an den Hippomaneae Adr. Jussieu ex Bartling (Euphorbiaceae), insbesondere den Mabeinae Pax \& K. Hoffm. Ph.D. dissertation, Hamburg, Germany.

Esser HJ (1997) A revision of Omalanthus (Euphorbiaceae) in Malesia. Blumea 42: 421-466.

Esser HJ (1998) New combinations in Microstachys (Euphorbiaceae). Kew Bulletin 53: 955-960.

Esser HJ (1999) A partial revision of the Hippomaneae (Euphorbiaceae) in Malesia. Blumea 44: 149-215.

Esser HJ (2001) Tribes Hippomaneae, Hureae, Pachystromateae. In: Radcliffe-Smith A (ed) Genera Euphorbiacearum. Royal Botanic Gardens, Kew, pp. 352-397.

Esser HJ (2002) A revision of Triadica Lour. (Euphorbiaceae). Harvard Papers in Botany 7: 17-21.

Esser HJ (2012) The tribe Hippomaneae (Euphorbiaceae) in Brazil. Rodriguesia 63: 209-225.

Gamble JS (1922) A manual of Indian timbers, $2^{\text {nd }}$ Edition. Sampson Low and Marston Co. Ltd, London.

Gilbert MG (1987) New and interesting species of Euphorbiaceae from Ethiopia. Kew Bulletin 42: 351-368.

IAWA Committee (1989) IAWA list of microscopic features for hardwood identification. IAWA Bulletin 10: 219-332.

Kribs DA (1935) Salient lines of structural specialization in the wood rays of dicotyledons. Botanical Gazette 96: 547-557.

Kruijt RC (1996) A taxononomic monograph of Sapium Jacq., Anomostachys (Baill.) Hurus., Duvigneaudia J.Léonard and Sclerocroton Hochst. (Euphorbiaceae tribe Hippomaneae). Bibliotheca Botanica 146: 109.

Luchi AE, Luiz, CPS \& Marcelo AM (2005) Anatomia comparada do lenho de Xylopia aromatica (Lam.) Mart. em áreas de cerrado e de plantação de Pinus elliottii Engelm. Brazilian Journal of Botany 28: 809-820.

Mennega AMW (1987) Wood anatomy of Euphorbiaceae in particular of subfamily Phyllanthoideae. Botanical Journal of Linnaean Society 94: 111-126.

Mennega AMW (2005) Wood anatomy of the subfamily Euphorbioideae. A comparison with subfamilies Crotonoideae and Acalyphoideae and the implications for the circumscriptions of the Euphorbiaceae. IAWA Journal 26: 1-68.

Metcalfe CR \& Chalk L (1950) Anatomy of the Dicotyledons, Vol. 2. Oxford at the Clarendon press.

Pearson RS \& Brown HP (1932) Commercial Timbers of India: Their Distribution, Supplies, Anatomical Structure, Physical and Mechanical Properties and uses, Vol. 2. Govt. of India, Central Publication Branch, Calcutta.

Radcliffe-Smith A (2001) Genera Euphorbiacearum. Royal Botanic Gardens, Kew, 464 p.

Rury PM (1985) Systematic and ecological wood anatomy of Erythroxylaceae. IAWA Bulletin 6: 365-397.

Raturi RD, Chauhan L \& Gupta S (2001) Indian Woods: their identification properties and uses. 6, Pub. I.C.F.R.E. Dehradun, India.

Webster GL (1994) Synopsis of the genera and suprageneric taxa of Euphorbiaceae. Annals of the Missouri Botanical Garden 81: 33-144.

Yatsenko-Khmelevskyi AA (1954) Osnovy i metody anatomicheskogo issledovaniya drevesiny (Principals and method of anatomical investigation of wood). Izdatel'stvo akademii Nauk SSSR, Moscow-Leningrad 337.

Zimmermann MH (1983) Xylem structure and the ascent of sap. Springer-Verlag, Berlin, 283 p. 